\title{
Wyzwania ksztaltowania nowego porządku międzynarodowego dla polityki Niemiec wobec Rosji w drugiej dekadzie XXI wieku
}

\section{Uwagi wstępne}

Celem opracowania jest próba syntetycznego ukazania znaczenia przemian porządku międzynarodowego dla polityki Niemiec wobec Rosji w drugiej dekadzie XXI w. Przemiany powyższe nabierają dużego przyspieszenia w toku postępującego procesu globalizacji. Ocena polityki Niemiec wobec Rosji (Russlandpolitik) musi dodatkowo uwzględniać zarówno następstwa dynamicznych zmian układu sił wewnątrzpolitycznych w Niemczech, jak też umocnienie się tendencji autorytarnych w Rosji wokół ekipy rządzącej na Kremlu. Cezura analizy obejmuje głównie okres drugiej dekady XXI w., ale w uzasadnionych sytuacjach uwzględnia się także okres wcześniejszy Rosji.

W analizie wykorzystano zarówno dostępne materiały źródłowe, zwłaszcza Aswärtiges-Amt (2007-2018) i Bundesregierung (2007-2018). Uwzględniono również nowsze pozycje literatury przedmiotu, zwłaszcza niemieckie: Klages (2017), Erler (2018), Maull (2017), amerykańskie: Kissinger (2014), Allison (2018), rosyjskie (Trenin, 2018) oraz prace polskie, w tym nowsze prace autora, zawierające obszerną bibliografię (Cziomer, 2018) oraz jego bieżącą obserwację uczestniczącą w powyższym zakresie. Rozległa problematyka badawcza, ograniczone ramy i objętość opracowania skłoniły autora zarówno do syntetycznego sformułowania własnych tez i hipotez badawczych, jak też rezygnacji z rozbudowy warsztatu naukowego, zwłaszcza w odniesieniu do nadmiernego stosowania przypisów.

\section{Ogólne tendencje niemieckich badań nad przemianami porządku międzynarodowego}

Porządek międzynarodowy jest ściśle związany z pojęciem ,system międzynarodowy”. Można go rozpatrywać w aspekcie teoretycznym i praktycznym jako bezpośrednie relacje między jego poszczególnymi elementami, zwłaszcza zaś państwami. W tym kontekście dla potrzeb poniższej analizy porządek międzynarodowy potraktowano ogólnie jako współzależność ukształtowanego historycznie systemu relacji w oparciu o obowiązujące normy, zasady, procedury i instytucje, regulujące współpracę między państwami, organizacjami oraz innymi uczestnikami stosunków 
międzynarodowych w płaszczyźnie polityczno-prawnej, bezpieczeństwa, gospodarki i kontaktów społecznych w wymiarze globalnym i regionalnym. Ważne miejsce w powyższym systemie interakcji zajmują przede wszystkim różne kategorie państw, w tym zwłaszcza mocarstwa wiodące, wokół których grupują się z reguły partnerzy i sojusznicy. Ważną cechą przywództwa mocarstw wiodących poza siłą militarną i potęgą gospodarczą jest dodatkowo zaufanie w oparciu o legalność, autorytet i efektywność postępowania w różnych zakresach działania międzynarodowego (Kissinger, 2014, s. 29).

Po przezwyciężeniu systemu dwubiegunowego zimnej wojny Wschód-Zachód 1989/1990 oraz rozpadu ZSRR (1991) doszło do ukształtowania się zachodniego neoliberalnego porządku międzynarodowego z dominującą rolą USA (Kukułka, 2004). Na początku lat 90 . w politologii amerykańskiej zakładano, iż wydarzenia powyższe stanowią koniec historii, gdyż dominacja prozachodniego porządku międzynarodowego doprowadzi do obiektywnego rozprzestrzenienia się zachodniej demokracji oraz gospodarki rynkowej w skali całego globu ziemskiego - Francis Fukuyama (Fukuyama, 1992). Okazało się to jednak jako podejście nierealistyczne ze względu na widoczne umocnienie się od początku XXI w. w skali europejskiej i pozostałych regionów świata tendencji populistycznych (Cziomer, 2011) oraz autorytarnych (Cziomer, 2016, s, 350-366). Rzutowało to niekorzystnie na rozwój wewnętrzny państw oraz relacje międzynarodowe.

Tendencje powyższe znalazły duże zainteresowanie w ramach niemieckich badań nad reżymami autorytarnymi w skali ogólnoświatowej. Ważną rolę odegrał w tym zakresie Instytut Politologii i Socjologii Uniwersytetu w Wuerzburgu, który na podstawie danych empirycznych z lat 1996-2012 przygotował Kombinowany Indeks Demokracji (Kombinierter Index der Demokratie - KID) (Lault, Kauf, 2012, s. 25-120). Państwa powyższe naniesiono na mapę świata, która zawiera szczegółowy wykaz reżymów demokratycznych i autorytarnych. Mapa potwierdza, iż w skali całego świata w XXI w. państwa zachodniej demokracji liberalnej są w mniejszości, a pozostałe tzw. państwa demokracji deficytowej (wadliwej), reżymy autorytarne, dyktatury, państwa upadłe, hybrydowe i inne znajdują większość globu ziemskiego. Ilustruje to poniżej mapa 1.

Ogólnie należy podkreślić, iż zasygnalizowane wyżej badania niemieckie przy porównywaniu różnych państw demokracji liberalnej lub autorytarnych brały pod uwagę takie czynniki rozwoju procesów polityczno-społecznych poszczególnych państw jak:

- prawa polityczne (politische Rechte): 1) całokształt procesu wyborczego, 2) pluralizm i uczestnictwo polityczne, 3) zasady trójpodziału władzy państwowej oraz sprawność funkcjonowania jego aparatu;

- wolności obywatelskie (buergerliche Freiheiten); 1) wolność wyznania, 2) wolność zgromadzeń i stowarzyszeń, 3) niezależność osobista i prawa indywidualne (Cziomer, 2016, s. 358-362).

W skali globalnej państwa orientacji neoliberalnej ustępują nie tylko jakościowo i ilościowo krajom autorytarnym, ale także w wielu wypadkach poziomem efektywności gospodarczej, zwłaszcza odniesieniu do Chin. Według szczegółowych danych amerykańskiej Fundacji Freedom House z 2014 r. - na 193 państw członkowskich 


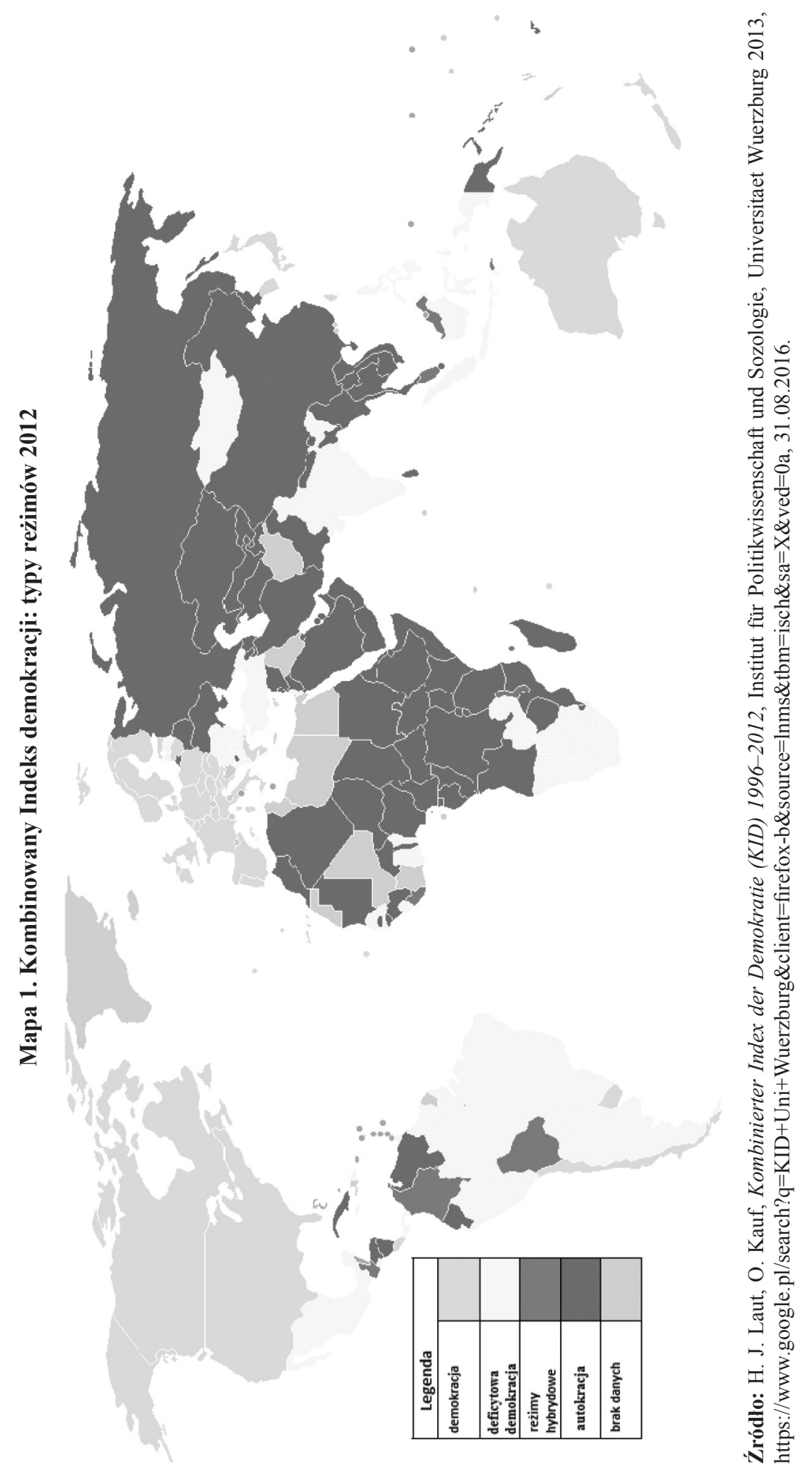


ONZ tylko 88 odpowiada ogólnym kryteriom demokracji liberalnej, a 107 z nich to państwa niedemokratyczne. $Z$ tych drugich 48 to typowe reżymy dyktatorskie, a 59 z nich można określić jako reżymy autorytarne, bądź też tzw. kraje zdefektowanej demokracji, rządzone przez zróżnicowane ambicjami politycznymi ekipy nacjonalistyczno-populistyczne (Laut, Kauf, s. 359).

Ważnymi przesłankami załamywania się roli oraz efektywności współpracy międzynarodowej czołowych państw zachodnich w latach 2008-2016/2017 była niezdolność państw demokratycznych Zachodu do rozwiązywania następujących kryzysów oraz konfliktów w skali globalnej, regionalnej, w tym również w Europie i samej UE:

a) ujemne następstwa światowego kryzysu finansowo-gospodarczego 2007 plus, w USA oraz w większości państw zachodnich, w tym również w UE;

b) kumulacja nierozwiązanych kryzysów międzynarodowych z udziałem USA oraz ich sojuszników i partnerów - europejskich na pozaeuropejskich obszarach kryzysowych (Afganistan, Irak, Libia, Syria - Państwo Islamskie na Bliskim Wschodzie $\mathrm{i}$ inne);

c) napięcia, kryzysy i konflikty w Europie - strefy euro 2010-2015, rosyjsko-ukraińskie (Krym i Donbas - od 2014 r., kryzys migracyjny 2015-2017 oraz kontrowersje wokół reformy unijnej w kontekście działań Wielkiej Brytanii na rzecz opuszczenia UE (Brexit) w latach 2016-2019;

d) ujawnienie się kryzysu przywództwa światowego oraz osłabienie więzi transatlantyckich America First „od 2017 r. po wyborze nowego prezydenta USA Donalda Trumpa w kontekście jego strategii politycznej America First” (Friedensgutachten, 2017).

Zasygnalizowane wyżej kryzysy polityczno-gospodarczo-finansowe osłabiły pozycję gospodarczo-polityczną rozwiniętych państw zachodnich w dobie postępującego procesu globalizacji. W trakcie kumulacji zasygnalizowanych wyżej napięć i kryzysów od połowy drugiej dekady XXI w. coraz większy wpływ na kształtowanie się nowego układu sił polityczno-militarnych w skali globalnej uzyskały USA, CHRL i Rosja. W 2018 r. doszło do wojny celno-handlowej zarówno między dwoma rywalami globalnymi USA i CHRL, jak też między partnerami oraz sojusznikami transatlantyckimi USA - z krami UE i NATO. Nie można też pominąć celowego działania otoczenia prezydenta Trumpa w kierunku utrzymania przez niego konserwatywnego elektoratu wyborczego w USA. W tym celu wycofuje on między innymi USA z wielu porozumień wielostronnych, narzucając zaś partnerom z pozycji mocarstwa dominującego korzystne dla Waszyngtonu rozwiązania unilateralne.

CHRL i Rosja jako państwa autorytarne dążą zdecydowanie do przekształcenia porządku neoliberalnego $\mathrm{w}$ system multilateralny, umożliwiający im ustanowienie swoich stref wpływów. Współdziałanie powyższe uległo dalszemu wzmocnieniu po nałożeniu przez USA i kraje UE sankcji na Rosję z tytułu aneksji przez ekipę Putina Krymu w 2014 r. Generalnie działania Moskwy i Pekinu nie są jednak w stanie całkowicie zlikwidować istniejących struktur i mechanizmów funkcjonowania porządku neoliberalnego, ale w wielu sytuacjach mogą je blokować lub modyfikować. Ma to miejsce przykładowo: w Radzie Bezpieczeństwa ONZ, czy też w ramach G-20, jak też na forum innych struktur i organizacji międzynarodowych. Dlatego też wielu specjalistów formułuje pogląd, iż w długim okresie przejściowym nie tylko Chiny i Rosja, 
ale także inne mocarstwa regionalne, w tym w większości kraje autorytarne - będą zmierzały do pozyskania partnerów wokół wspólnych interesów i celów bądź to do tworzenia określonych ,koalicji chętnych”, bądź też konkurencyjnych sojuszy wokół określonych programów lub projektów funkcjonowania. Koalicje powyższe nie będą miały trwałego charakteru, a jedynie grupowały określone państwa w celu rozwiązywania konkretnych problemów i zadań. Nie mają one jednak ani spójnych wizji przyszłych struktur, ani też zasad funkcjonowania systemów multilateralnych.

Możne generalnie założyć, iż istniejący jeszcze przejściowo zachodni porządek neoliberalny nie utrzyma się w przyszłości w dotychczasowej formie. Będzie on ulegał w nadchodzących latach dalszym zmianom i modyfikacjom. Według niektórych prognoz amerykańskich jeden z możliwych wariantów przyszłego porządku międzynarodowego będzie miał kształt podobny do trójstopniowego modelu szachowego. Może on hipotetycznie funkcjonować w trzech płaszczyznach: 1) militarnej-z utrzymaniem unilateralnej dominacji przez USA, 2) gospodarczej - grupującej mocarstwa oraz państwa dominujące ekonomicznie w układach regionalnych, 3) współpracy transnarodowej - obejmującej pozostałe państwa oraz organizacje pozarządowe (Nye, 2011).

Przy ocenie powyższego modelu należy brać dodatkowo pod uwagę możliwość dalszego wpływu na kształt przyszłego porządku międzynarodowego - procesu przyspieszenia globalizacji oraz digitalizacji. Wpłyną one w przyszłości, w dużym stopniu, nie tylko na przyspieszenie rozwoju technologicznego współczesnego świata, lecz rzutowały będą także na dalszą ewolucję układu sił i współpracy międzynarodowej, zdolność do szybkiego wdrożenia oraz wykorzystania przez poszczególne państwa zdobyczy nauki i nowych technik łączności, komunikowania, sztucznej inteligencji i innych (Teissen, 2017, s. 73 i nast.).

Dla Niemiec, jako sektorowego mocarstwa gospodarczo-handlowego o globalnych interesach, badania nad porządkiem międzynarodowym posiadają nie tylko wymiar teoretyczny, lecz także znaczenie dla praktyki politycznej. Posiadają one z reguły charakter interdyscyplinarny i koncentrują się między innymi na analizie powiązanych ze sobą płaszczyzn działania państw, organizacji międzynarodowych oraz innych uczestników pozapaństwowych. Poniżej ograniczamy się do przedstawienia preferowanych badań czołowego Instytutu Niemieckich Badań Międzynarodowych i Bezpieczeństwa w Berlinie w zakresie porządku międzynarodowego, bezpieczeństwa oraz gospodarki i społeczeństwa światowego. Ilustruje poniższe zestawienie nr 1:

\section{Zestawienie nr 1}

Orientacyjne Ramy Badawcze Fundacji Nauka i Polityka w Berlinie na lata $2017 / 2018$

A) porządek międzynarodowy:

1) struktury globalne i regionalne,

2) wybrani uczestnicy (aktorzy stosunków międzynarodowych ) w określonych konstelacjach (np. system ONZ, formaty G-7/8, G-20, USA, UE, kraje wschodzących rynków),

3) regionalne przesunięcia w układzie sił (Kraefteverschiebungen),

4) integracja europejska - w kontekście dynamiki przekształceń wewnętrznych, członków i kandydatów, 
5) UE - w kontekście nowych wyzwań i roli międzynarodowej;

B) bezpieczeństwo międzynarodowe:

1) kontrola zbrojeń, budowania zaufania, nierozprzestrzenianie broni (nuklearnej),

2) kryzysy i konflikty w regionach strategicznych (np. na Bliskim i Środkowym Wschodzie),

3) terroryzm transnarodowy i zorganizowana przestępczość,

4) stabilizacja upadłych państw,

5) rozładowanie oraz wczesne rozpoznanie kryzysów,

6) wyzwania technologiczne,

7) polityka rozbrojeniowa (Ruestungspolitik);

C) gospodarka i społeczeństwo światowe:

1) trudności wzrostu i konflikty na tle podziału dóbr,

2) regionalne i globalne kryzysy finansowe,

3) polityka handlowa i kooperacja międzynarodowa,

4) polityka klimatyczna, problemy energetyczne oraz zrównoważony rozwój,

5) ucieczka, migracja i rozwój,

6) demografia (Orienterungsrahmen für Forschung SWP, 2018).

Z wyszczególnionych wyżej założeń badawczych, w odniesieniu do postępujących zmian porządku międzynarodowego, wynikało szereg ważnych wniosków i postulatów praktycznych dla polityki rządu federalnego wobec Rosji. Będą one przedmiotem analizy w dalszej części opracowania.

\section{Istota nowej strategii polityki Niemiec wobec Rosji}

Po zjednoczeniu Niemiec w 1990 r., zwłaszcza zaś w okresie rządów koalicji socjaldemokratyczno-zielonej (SPD/Sojusz 90/Zieloni - na czele z kanclerzem Gerhardem Schroederem w latach 1998-2005, doszło do osobistego zbliżenia Schroedera z prezydentem Rosji Władimirem Putinem. Skutkowało to zacieśnieniem współpracy dwu- i wielostronnej Niemiec z Federacją Rosyjską. Rosja stała się formalnie nie tylko partnerem strategicznym rządu RFN, lecz także - za ich poparciem - całej UE. Status powyższy utrzymano także w dwóch pierwszych kadencjach kanclerz Anglei Merklel - Wielkiej Koalicji CDU/CSU i SPD (2005-2009), koalicji chadecko-liberalnej CDU/CSU I FDP oraz ponownie w trzeciej - Wielkiej Koalicji CDU/CSU i SPD (2009-2013). Znaczenie współpracy Niemiec z Rosją miało również istotne znaczenie w trakcie wypracowania na przełomie lat 2011/2012 przez środowiska naukowe wspólnie ze Sztabem Planowania AA dokumentu:

, Globalizację ksztaltować - partnerstwo rozbudować - odpowiedzialność dzielić", którego rangę podniesiono, poprzez uchwałę Bundestagu, do oficjalnej strategii rządu federalnego. Dokument powyższy przedstawiał priorytety całokształtu polityki zagranicznej i bezpieczeństwa Niemiec, uwzględniające w szerszym zakresie stanowisko w odniesieniu do „współdecydujących mocarstw” (Gestaltungsmaechte). Rosję jako stałego członka Rady Bezpieczeństwa ONZ oraz kraj członkowski Grupy BRICS (Brazylia, Chiny, Indie i Rosja) zaliczono do „,nowych i centrów sity” 
(neue Kraftzentren), które odgrywały coraz większą rolę polityce międzynarodowej, w tym zwłaszcza w grupie krajów - G-20 (Gestaltungskonzept der Bundesregierung, 8.02.2012).

Strategia powyższa zawierała jedynie ogólne założenie i priorytety, pozostawiając ośrodkowi decyzyjnemu rządu federalnego (Urząd Kanclerski oraz poszczególne resorty, zwłaszcza - AA (MSZ), finansów, gospodarki i energetyki, obrony, współpracy zagranicznej i rozwoju) swobodę w podejmowaniu decyzji zgodnie z obowiązującym prawem i procedurami (Cziomer, 2010). Następowało to oficjalnie w ramach deklaracji rządu federalnego uzgodnionych na forum Bundestagu przez kanclerz Merkel. Niezależnie od kompetencji poszczególnych resortów w ramach ,„polityki rosyjskiej” (Russlandpolitik) ostatnie słowo zawsze należało do szefa rządu. Merkel - podobnie, jak jej poprzednicy - H. Kohl i G. Schroeder - traktowała podejmowanie kluczowych decyzji w polityce wobec Rosji w latach 2013-2018 jako swoją ,główną kompetencję" (Chefsache) (Pickertt, 2017). W tym kontekście warto jednak podkreślić, iż w ramach koalicji CDU/CSU/SPD po 2013 r. resortami spraw zagranicznych i gospodarczo-energetycznych kierowali czołowi politycy SPD - F. W. Steinmeier (2013-2017 MSZ) oraz S. Gabriel (2013-2017 wicekanclerz, gospodarki i energii, od 2017/2018 - szef MS), którzy nadal pozostawali w bezpośrednich kontaktach z byłym kanclerzem G. Schröderem - po 2005 r. szefem Rady Nadzorczej Gazpromu, od 2018 - Rosnieftu. Był on czołowym lobbystą prezydenta W. Putina w Niemczech oraz w czołowych krajach UE (Schoellgen, 2015 ). Ministrowie Steinmeier i Gabriel - podobnie jak zdecydowana większość czołowych polityków SPD - byli zwolennikami współpracy Niemiec z Rosją, niezależnie od konieczności częściowego zdystansowania się od polityki Rosji w poszczególnych fazach kryzysu ukraińskiego w latach 2014-2018. Podczas swoich wizyt w Moskwie w latach 2014-2017 często rozmawiali również poza protokołem bezpośrednio z Putinem.

Generalnie strategię rządu CDU/CSU/SPD wobec Rosji w dobie przemian porządku międzynarodowego oraz konfliktu rosyjsko-ukraińskiego w latach 2014-2018 można syntetycznie określić w trzech punktach:

1) podtrzymywanie gotowości do dialogu z Rosją w celu zakończenia działań zbrojnych oraz przywrócenia pokoju i stabilizacji na terenie Ukrainy Wschodniej (Donbas);

2) gotowość wypracowania i wdrożenia sankcji zachodnich jako instrumentu nacisku na Rosję;

3) udzielenie pomocy finansowej oraz wsparcia gospodarczego dla Ukrainy (Cziomer, 2018, s. 196 i nast.).

Równocześnie w wielu analizach niemieckich zwraca się uwagę na umocnienie się w Rosji systemu autorytarnego, w którym W. Putin i jego najbliższe otoczenie podjęło interwencję zbroją przeciwko Ukrainie (aneksja Krymu - luty 2014 r. oraz udzieliło silnego poparcia dla działań separatystów w Donbasie z motywów wewnętrznych w celu zwiększenia własnej popularności oraz dodatkowej legitymizacji sprawowania władzy. W dalszej kolejności Putin i jego ekipa dążyły do osłabienia wpływów państw zachodnich w Rosji oraz na całym obszarze poradzieckim, aby wykluczyć możliwość wybuchu „kolorowych rewolucji”, jak również uzyskania przez Ukrainę i Gruzję szans potencjalnego członkostwa w NATO - MAP. Zabiegano o strategiczne 
umocnienie pozycji i obecności Rosji w rejonie Morza Czarnego, Śródziemnego, na Zakaukaziu i na Bliskim Wschodzie Syria (Reitschuster, 2016).

W łonie elit niemieckich (politycznej, intelektualnej i medialnej) ujawniły się w latach 2014-2015 silne tendencje dwóch zwalczających się obozów - zwolenników i przeciwników polityki Rosji wobec Zachodu (Putin Versteher) oraz (Putin Gegner). Wśród sił politycznych wyrażających sympatię i gotowość do współpracy z Kremlem byli zarówno niektórzy czołowi politycy współrządzących - SPD, CSU i częściowo CDU, jak też opozycyjnej Partii Lewicowej i wzrastającej w siłę populistycznej Alternatywy dla Niemiec (AfD) oraz współpracującego z nią głównego ruchu protestu antyislamskiego w Niemczech - PEGIDA (Cziomer, 2015, s. 489-502). Z chwilą aneksji Krymu, działań zbrojnych w Donbasie oraz stosowania z udziałem Niemiec sankcji zachodnich - Rosja utraciła z punktu widzenia rządu federalnego dawną pozycję „partnera strategicznego" Niemiec i UE. Były szef MSZ - Siegmar Gabriel proponował traktować Rosję równocześnie jako „sąsiada, partnera i rywala” (Gabriel, 2018, s. 113). Natomiast w umowie koalicyjnej CDU/CSU i SPD z 8 lutego 2018 r. Rosji poświęcono obszerny akapit, w którym po krytycznej ocenie polityki Rosji po 2013 r. w odniesieniu do konfliktu na Ukrainie, stwierdzono między innymi w końcowej części: „... Podtrzymujemy mocno naszą wizję ustanowienia wspólnej przestrzeni gospodarczej od Lizbony po Władywostok. Obie strony i cała Europa mogłyby na tym skorzystać. Celem naszej polityki wobec Rosji pozostaje powrót do wzajemnego zaufania oraz pokojowego ułożenia naszych stosunków na bazie korzystnego rozwiązania różnicy interesów, umożliwiające ponowne osiągnięcie bliskiego partnerstwa..." (Ein neuer Aufbruch für Europa, 2018, s. 145).

Reasumując można zatem stwierdzić, iż rząd CDU/CSU/SPD na czele z kanclerz A. Merkel nadal był długofalowo zainteresowany dążeniem do bliskiej współpracy z Rosją. Jednak aneksja Krymu i popieranie przez Kreml separatystów na Wschodzie Ukrainy, równolegle do forsowania przez Niemcy wraz z USA i krajami UE sankcji zachodnich wobec Rosji w latach 2014-2018 - nie sprzyjało dalszemu pogłębieniu współpracy niemiecko-rosyjskiej. Stawała się ona coraz bardziej złożona między innymi ze względu na trudności wewnętrzne rządu CDU/CSU/SPD oraz zdecydowane podważanie przez Chiny i Rosję korzystnego dla Niemiec neoliberalnego porządku międzynarodowego w drugiej dekadzie XXI w.

\section{Wyzwania realizacji polityki Niemiec wobec Rosji}

Przy ocenie realizacji strategii polityki kanclerz Merkel wobec Rosji w kontekście jej intensywnych kontaktów z prezydentem W. Putinem w latach 2014-2018/19 można wyróżnić dwa wyraźne okresy:

1) zainicjowanie od początku 2014 r. wysiłków w kierunku pokojowego rozwiązania konfliktu rosyjsko-ukraińskiego przez negocjacje w sprawie zawieszenia broni w ramach tzw. formatu normandzkiego (Niemcy, Francja, Rosja i Ukraina na różnych szczeblach) przy równoczesnym stosowaniu zachodnich sankcji wobec Rosji. Jego najważniejszym osiągnięciem było zawarcie za pośrednictwem OBWE pierwszego zawieszenia broni (październik 2014) oraz podpisanie po długich ro- 
kowaniach porozumienia pokojowego Mińsk II - 12 luty 2015 r., w którym obok kolejnego zawieszenia broni uzgodniono procedurę częściowej „federalizacji” Donbasu, oraz przeprowadzenia w przyszłości wolnych wyborów;

2) trudności wdrożenia porozumienia Mińsk II ze względu na istotne różnice interesów między Kremlem a Kijowem oraz Rosją a krajami NATO i UE (Cziomer, 2015, s. 39-57).

Równocześnie ekipie rządzącej Putina udało się w latach 2015-2018 doprowadzić do umocnienia pozycji międzynarodowej Rosji (między innymi przez interwencję zbrojną w Syrii od września 2015 r. ), przy równoczesnej polityce konfrontacji z USA, oraz krajami NATO i UE w aspekcie propagandowym, ataków cybernetycznych hakerów itp., łącznie z bezpośrednim wspieraniem finansowym przez Kreml ruchów populistycznych w krajach UE (Wehner, 2017).

Natomiast poważnemu osłabieniu uległa stopniowo pozycja kanclerz Merkel w Niemczech oraz na arenie międzynarodowej ze względu na:

- powszechną krytykę jej niekonsekwentnego stanowiska w sprawie otwartych granic, umożliwiających masową imigrację do Niemiec ok. 1 mln nielegalnych uchodźców z Bliskiego Wschodu oraz Afryki, w latach 2015-2016 (Alexander, 2017);

- postępujący spadek popularności kanclerz Merkel w Niemczech ze względu na klęski CDU i CSU i SPD w wyborach krajowych 2016-2017 (np. utratę przez $\mathrm{CDU} / \mathrm{CSU}$, na rzecz populistyczno-nacjonalistycznej AfD, 1,5 mln byłych członków i sympatyków chadecji w wyborach do Bundestagu 24 września 2017 r.) (Cziomer, 2017, s. 43-62);

- nasilenie się krytyki pod adresem polityki Niemiec w NATO, jak również bezpośrednio samej kanclerz Merkel nie tylko ze strony populistów niemieckich i europejskich, lecz przede wszystkim ze strony administracji nowego prezydenta USA - D. Trumpa od początku 2017 r. (Cziomer, 2018, s. 177-167).

W tej sytuacji Merkel niespodziewanie zrezygnowała pod koniec 2018 r. z przewodnictwa CDU, zachowując jedynie do końca kadencji urząd kanclerza federalnego.

Zasygnalizowane wyżej wybiórczo wydarzenia i tendencje o charakterze wewnętrznym i międzynarodowym rzutowały również negatywnie na rozwój współpracy niemiecko-rosyjskiej w różnych dziedzinach i zakresach w latach 2014-2018. Zarówno Niemcy, jak też Rosja były jednak, od przełomu 2015/2016, zainteresowane powrotem do ożywienia współpracy wzajemnej w wymiarze bilateralnym i wielostronnym. W ujęciu syntetycznym najistotniejsze przesłanki działań oraz powyższych zabiegów można przedstawić wybiórczo następująco:

- wymuszenie modyfikacji polityki nowego szefa MSZ w 2018 r. - Heiko Maasa (SPD) ze względu na naciski ze strony kierownictwa socjaldemokracji na szczeblach federalnym oraz nowych krajów związkowych. Wyrazem tego była między innymi reaktywacja 12 listopada 2018 r. posiedzenia Wysokiej Niemiecko-Rosyjskiej Grupy Roboczej ds. Bezpieczeństwa na szczeblu wiceministrów spraw zagranicznych na temat przyszłości układu INF USA-Rosja (o redukcji broni nuklearnej średniego zasięgu z 1987 r.), który posiada ogromne znaczenie strategiczno-militarne dla RFN. Prezydent D. Trump oskarża Rosję o łamanie jego postanowień i grozi wypowiedzeniem go przez USA. Na 2019 rok przewiduje się 2 dalsze spotkania: 1) na temat walki z terroryzmem, 2) w odniesieniu do nowej fazy kryzysu 
ukraińskiego i syryjskiego. Dialog z Rosją jest o tyle istotny, gdyż administracja amerykańska D. Trumpa nie jest zainteresowana szerszymi konsultacjami na temat układu IMF z 1987 r. ze swoimi sojusznikami, w tym również z Niemcami;

- od początku 2019 r. Niemcy zostały kolejny raz wybrane na niestałego członka Rady Bezpieczeństwa ONZ (Cziomer, 2018, s. 167 i nast.). Warto w tym miejscu podkreślić, iż po krótkiej przerwie w 2014 r. regularne konsultacje polityczne i gospodarcze niemiecko-rosyjskie odbywają się na wszystkich szczerbach od 2015 r. Dotyczy to także szerszych kontaktów dwustronnych społeczno-polityczno-kulturalnych i naukowych, w tym działalności Forum Niemiecko-Rosyjskiego oraz Dialogu Petersburskiego.

Bardzo ważne znaczenie dla niemiecko-rosyjskiej współpracy gospodarczej posiada wymiana handlowa, której łączne obroty w 2012 r. osiągnęły rekordową wysokość - 80,8 mld euro. Ze względu na sankcje zachodnie wobec Rosji, a zwłaszcza spadek cen surowców energetycznych - wartość wymiany handlowej spadła się w 2016 r. o blisko $40 \%$ do stanu $-48,0$ mld euro. Od 2017 r. nastąpił znowu jej stopniowy wzrost do 52,7 mld euro rocznie. Równocześnie w latach 2013-2016 nastąpił znaczny spodek liczby firm niemieckich w Rosji z 6000 do 5237, zwłaszcza z nowych krajów związkowych, czyli byłej NRD. Dlatego sporo polityków wschodnioniemieckich różnych opcji politycznych opowiada się zarówno przeciwko utrzymaniu sankcji zachodnich, w tym także RFN, oraz rozbudowę współpracy gospodarczej z Rosją (Cziomer, 2018a, s. 51-68).

W latach 2014-2017 ze względu na konflikt wokół Ukrainy oraz związane z tym sankcje zachodnie Rosja dokonała zdecydowanego „,zwrotu w kierunku wschodnim”, zacieśniając współpracę z Chinami (CHRL). Miało to nie tylko ogromne znaczenie polityczno-strategicze, zmierzające do podważenia dominującego neoliberalnego porządku międzynarodowego na czele z USA, lecz także określone implikacje dla współpracy gospodarczej między Niemcami a Rosją i Chinami. Chiny umocniły bowiem swoją pozycję jako pierwszy partner handlowy Rosji (2016 - 1 miejsce o wartości 59,5 mld euro), zastępując Niemcy jako drugiego partnera handlowego Rosji (2016 - 2 miejsce o wartości 36,6 mld euro) (Erler, 2018, s. 46 i nast).

W tym kontekście - Niemcy jako pierwszy partner handlowy zarówno Chin, jak i Rosji - w UE i całej Europie są zarówno zainteresowane współpracą z utworzoną przez Rosję - Unią Euroazjatycką (2015), jak też z długofalowym projektem Chin. „Nowym Jedwabnym Szlakiem” (od 2013/2014). Powyższe działania Niemiec nabierają dodatkowo dużego znaczenia strategicznego w kontekście ujemnych dla Berlina i relacji transatlantyckich - następstw forsowanej konsekwentnie, od 2017 r., polityki nowej administracji amerykańskiej prezydenta D. Trumpa - America first. USA krytycznie odnoszą się dodatkowo do budowy drugiej nitki Gazociągu Północnego (Nordstreem) realizowanej przez rosyjski koncern - Gazprom na Bałtyku. Z kolei rząd CDU/CSU/SPD traktuje powyższą inwestycję jako przedsięwzięcie komercyjne, posiadające decydujące znaczenie dla zaopatrzenia Niemiec w surowce energetyczne. Ze względu na krytykę Nordstreemu przez niektóre kraje UE, zwłaszcza zaś Polskę, nie można całkowicie wykluczyć działań USA na rzecz umieszczenia na liście sankcji antyrosyjskich, koncernów niemieckich, współpracujących z Gzapromem w budowie 2 nitki Gazociągu Północnego (Ischinger, 2018, s. 273 i nast.).

Mimo pogarszających się relacji Rosji z USA, UE i NATO w Niemczech nie milkną głosy zwolenników zniesienia sankcji zachodnich oraz dalszego pogłębienia 
współpracy niemiecko-rosyjskiej. W tym kontekście na szczególną uwagę zasługuje opublikowany w 2018 r. apel pt.: „Dlaczego potrzebujemy pokoju i przyjaźni z Rosją? Odezwa do wszystkich" (Bahr, 2018). W obszernej publikacji będącej pracą zbiorową oraz pewnego rodzaju manifestem poparcia intelektualistów i polityków dla właściwego architekta polityki wschodniej i niemieckiej (1970-1974), w tym zwłaszcza głównego negocjatora układu RFN-ZSRR z 10 sierpnia 1970 r. Egona Bahra. Jej autorami są 23 osoby - intelektualiści, uczeni, dyplomaci, artyści, dziennikarze, przedstawiciele głównych orientacji politycznych oraz innych dziedzin życia publicznego - przedstawiają własne przemyślenia i argumenty na rzecz zacieśnienia współpracy niemieckorosyjskiej. Niektórzy z nich postulują potrzebę dążenia przez Niemcy do zwiększenia i pogłębienia współpracy polityczno-gospodarczej z autorytarną ekipą rządzącą na Kremlu na czele z W. Putinem.

Niemiecka opinia publiczna pod wpływem szerokiego wachlarza zróżnicowanych informacji na temat Rosji oraz relacji niemiecko-rosyjskich w massmediach, oficjalnych wypowiedzi rządu federalnego i partii politycznych, zajmuje bardziej wyważoną, choć w większości wypadków życzliwą postawę wobec znaczenia roli i miejsca Rosji w polityce międzynarodowej. W oparciu o reprezentatywne badania demoskopijne z połowy 2017 r. stanowisko niemieckiej opinii publicznej przedstawia się następująco:

1) wśród zewnątrzpolitycznych priorytetów polityki zagranicznej RFN - poprawa stosunków niemiecko-rosyjskich znalazła poparcie - $63 \%$ respondentów (po ochronie klimatu $-83 \%$, prowadzeniu dyplomatycznych negocjacji rozbrojeniowych $-73 \%$ oraz zwalczaniu przyczyn nielegalnych migracji z Bliskiego Wschodu i Afryki - 71\%);

2) na pytanie odnośnie wpływów Rosji w polityce światowej uzyskano następujące wskazania respondentów - a) wpływ duży $-57 \%$, b) wpływ bardzo duży $-23 \%$, c) bardzo ograniczony $-18 \%$;

3) na pytanie odnośnie źródeł siły Rosji w polityce międzynarodowej odpowiedzi brzmiały kolejno: a) wojsko oraz broń atomowa - 77\%, b) bogactwo surowcowe - 75\%, c) autorytarny system sprawowania władzy - 50\%, d) położenie geopolityczne $-46 \%$, e) zdolność wywierania wpływu na przebieg wyborów w innych krajach - 35\% (Cziomer, 2018, s. 218-219).

\section{Konkluzja}

Przyspieszenie kształtowania w drugiej dekadzie XXI w. przemian neoliberalnego porządku międzynarodowego z dominującą rolą USA w system multilateralny posiada ważne znaczenie dla kształtowania nowej strategii w polityce Niemiec wobec Rosji. Proces powyższy następuje w niekorzystnej sytuacji geopolitycznej dla Niemiec w kontekście osłabienia relacji transatlantyckich w ramach polityki nowego prezydenta USA - D. Trumpa „America first”, pogłębiającego się kryzysu UE oraz podtrzymywania przez Rosję - na tle jej zwrotu w kierunku bliskiej współpracy z Chinami - zamrożonego konfliktu Separatystów w Donbasie na terenie Ukrainy Wschodniej. Mimo osłabienia pozycji politycznej, kanclerz A. Merkel w Niemczech - rząd Wielkiej Koalicji CDU/CSU/SPD zmierza do zachowania stabilności i spójności UE, w tym zwłaszcza poprzez dążenie do trudnego ożywienia współdziałania w ramach 
„osi Berlin-Paryż”. Ważnym elementem działania RFN w tym zakresie jest dążenie do utrzymania dobrych relacji gospodarczo-politycznych z Rosją i Chinami.

\section{Bibliografia}

Alexander R, (2017), Die Getriebenen, Merkel und die Flüchtlingspolitik, Report aus dem Innern der Macht, München.

Allison G. (2018), Skazani na wojnę? Czy Ameryka i Chiny unikna pułapki Tukiddydesa, BielskoBiała.

Auswaertiges-Amt (2007-2018), Aussen- und Sicherheitspolitik, Beziehungen zu Russland (20072018), https://www.auswaertiges-amt.de/de/.

Auswärtiges Amt (21.11.2018), Warum der Dialog mit Russland wichtig ist Amt, https://www. auswaertiges-amt.de/de/aussenpolitik/laender/russischefoederation-node/dialog-mit-russland/2162978.

Bahr A. (Hrsg) (2018),Warum wir Frieden und Freundschaft mit Russland brauchen, Ein Anruf an alle, Frankfurt/Main-Berlin.

Bundesregierung (2007-2018), Bundesministerien, Bundeskanzlerin, https://www.bundesregierung. de/breg-de/bundesregierung/bundesministerien.

Cziomer E. (2010), Polityka zagraniczna Niemiec w dobie nowych wyzwań globalizacji, bezpieczeństwa międzynarodowego oraz integracji europejskiej po 2005 roku, Warszawa.

Cziomer E. (red.) (2011), Populizm wyzwaniem dla dobrego rządzenia i wspótpracy międzynarodowej, „Krakowskie Studia Międzynarodowe” nr 4(VIII), Kraków.

Cziomer E. (2015), Implikacje kryzysu ukraińskiego dla polityki Niemiec wobec Rosji w latach 2013-2014, w: Bezpieczeństwo międzynarodowe. Polska - Europa - Świat, red. J. Zając, A. Włodkowska-Bagan, M. Kaczmarski, Warszawa, s. 489-502.

Cziomer E. (2015), Niemcy wobec geopolitycznego wymiaru kryzysu ukrainskiego 2013-2015, w: Przemiany bezpieczeństwa $i$ wspótpracy międzynarodowej w drugiej dekadzie XXI w., cz. 2: Geopolityczny wymiar kryzysu ukraińskiego, red. E. Cziomer, „Krakowskie Studia Międzynarodowe" (KSM), nr 2(XII), Kraków, s. 39-57.

Cziomer E. (2016), Wspótczesne wyzwania wspótpracy międzynarodowej państw demokratycznych z autorytarnymi na przykładzie Niemiec, w: Demokracja współczesna. Wymiar polski i międzynarodowy, red. J. Kornaś, Ł. Danel, Toruń, s. 39.

Cziomer E. (2017), Implikacje wyborów federalnych z 24 września 2017 r. i masowego napływu uchodźców dla przemian wewnętrznych oraz roli Niemiec w UE, w: Kryzys funkcjonowania oraz roli międzynarodowej UE $w$ drugiej dekadzie XXI w., red. E. Cziomer, „Krakowskie Studia Międzynarodowe", nr 2(XIV), cz. 2, Kraków, s. 43-62.

Cziomer E. (2018), Wyzwania nowej roli międzynarodowej Niemiec w dobie globalizacji, kryzysów polityczno-finansowych po 2007 roku, Kraków.

Cziomer E. (2018a), Niemcy wobec międzynarodowych implikacji wspótpracy Chińskiej Republiki Ludowej z Federacja Rosyjska w drugiej dekadzie XXI w., w: Znaczenie wspótpracy Chin z Rosja dla ksztaltowania nowego porządku międzynarodowego w XXI wieku, „Krakowskie Studia Międzynarodowe”, nr 1(XV), red. E. Cziomer, Oficyna Wydawnicza AFM, Kraków, s. 51-68.

Deutschlands außenpolitischen Prioritäten (Mai/Juni 2017), „Internatiobale Politik“, Nr 3, https:// zeitschrift-ip.dgap.org/de/ip-die-zeitschrift/archiv/jahrgang-2017/juli-august/deutschlandsaussenpolitische-prioritaeten.

Ein neuer Aufbruch für Europa (2018), Eine neue Dynamik für Deutschland, Ein neuer Zusammenhalt für unser Land. Koalitionsvertrag zwischen CDU, CSU und SPD, 9. Legislaturperiode, Berlin. 
Erler G. (2018), Weltordnung. Ohne den Westen? Europa zwischen Russland, China und Amerika, Freiburg-Basel-Wien.

Friedensgutachten (2017), Die Erosion der bisherigen Weltordnung, [Hrsg.] Institute für Friedensforschung, Bonn-Frankfurt am Main-Hamburg-Münster.

Fukuyama F. (1992), The End of History and the Last Man, Free Press.

Gabriel S. (2918), Zeitwende in der Weltpolitik, Freiburg-Basel-Wien.

Gestaltungskonzept der Bundesregierung. Globalisierung gestalten-Partnerschaft ausbauen - Verantwortung teilen. Konzept der Bundesregierung (2012), 8.02.2012, http://www.auswaertigesamt.de/cae/servlet/contentblob/608384/publicationFile/169965/Gestaltungsmaechtekonze.pdf.

Ischinger W. (2018), Welt in Gefahr. Deutschland und Europa in unsicheren Zeiten, Berlin.

Kissinger H. (2014), Weltordnung, München.

Klages W. (2017), Zeitwende, Strategie und Ziele deutscher Außenpolitik im 21. Jahrhundert, BadenBaden.

Kukułka P. J (2004), Historia stosunków międzynarodowych 1945-2004, Warszawa, s. 25-34.

Laut H. J., Kauf O. (2012), Demokratiemessung. Der KID als aggiertes Mass für die kompirastive Forschung.Befunde der Regimeentwicklung von 1996-2000, „Würzburger Arbeitspapiere zur Politikwissenschaft und Sozialforschung", Nr 2, Würzburg.

Maull H. W. (Hg.) (2017), Auflösung oder Ablösung, Die internationale Ordnung im Umbruch, SWP-Studie, Berlin

Maull H. G. (Hg.) (2017), Auflösung oder Ablösung, Die internationale Ordnung im Umbruch, SWPStudie, Berlin.

Meister S. (2016), Putin als Wille und Vorstellung, „Internationale Politik“, 5 September-Oktober 2016 DGAP Berlin, s. 132-136, https://zeitschrift-ip.dgap.org/de/ip-die-zeitschrift/archiv/ jahrgang-2016/september-oktober/putin-als-wille-un.

Nye J. S. (2011) Macht im 21. Jahrhundert. Politische Strategien für ein Neues Zeitalter, Siedler Verlag, München.

Orienterungsrahmen für Forschung SWP (2018), Deutzsches Institut für Internationale Sicherheit und Politik, Berlin 2017/2018, https:/www.swp-berlin.org/fileadmin/contents/products/ sonstiges/Orientierungsrahmen_2017_18.pdf.

Pickertt H. (Hrsg.) (2017), Merkel. Eine kritische Bilanz, München.

Reitschuster (2016), B. Putin verdeckter Krieg. Wie Moskau den Westen destabilisiert, Berlin.

Steinmeier F. W (2016), Flugschreiber. Notizen aus der Aussenpolitik in Krisenzeiten, Berlin.

Schoellgen G. (2015), Gerhard Schroeder. Die Biographie, München.

Teisen H. (2017), Der Westen und die Weltordnung, Stuttgart.

Trenin D. (2018), Deutschland und Russland: Von der Entfremdung zu einer neuen Nachbarschaft, Canergie Moscow Center, https://carnegieeurope.eu/2018/05/31/de-pub-76536.

Wehner M. (2017), Putin Kalter Krieg. Wie Russland den Westen vor sich hertreibt, München.

Winkler H. A. (2015), Geschichte des Westens. Die Zeit der Gegenwart, München.

\section{Streszczenie}

Artykuł podejmuje ważny oraz złożony problem, związany z analizą wpływu kształtowania nowego porządku międzynarodowego dla polityki Niemiec wobec Rosji. Składa się on z trzech części:

1) ogólne tendencje niemieckich badań nad przemianami porządku międzynarodowego; 
2) istota nowej strategii polityki Niemiec wobec Rosji;

3) wyzwania realizacji polityki Niemiec wobec Rosji.

Jako czołowe państwo UE o rozbudowanych interesach globalnych Niemcy będące czwartą gospodarką światową korzystały w XXI w. w dużym stopniu ze zdobyczy globalizacji oraz dominującego w skali całego świata - międzynarodowego porządku neoliberalnego. W tym kontekście pierwszoplanowe znaczenie dla Niemiec miała współpraca z Rosją jako partnerem strategicznym. Uległa ona ograniczeniu po przejściu Rosji do polityki jawnej agresji przeciw Ukrainie w 2014 r. (aneksja Krymu oraz wsparcia dla Separatystów w Donbasie), podważając tym samym istniejący porządek międzynarodowy. W konsekwencji nałożenia na Rosję sankcji - przez USA, kraje NATO i UE - ekipa rządząca na Kremlu na czele z W. Putinem dokonała zwrotu w kierunku pogłębienia współpracy z Chinami, zmierzając zarazem do osłabienia wpływów USA i budowy konkurencyjnego porząaku multilateralnego. Napięcia i trudności w relacjach transatlantyckich na tle polityki „America first” nowego prezydenta USA D. Trumpa od początku 2017 skłoniła Niemcy do podtrzymania relacji z Rosją oraz Chinami w wymiarze bilateralnym i wielostronnym.

Słowa kluczowe: Niemcy, Rosja, nowy porządek międzynarodowy, współpraca polityczna i gospodarcza

\section{Challenges for shaping a new international order for Germany's policy towards Russia in the second decade of the 21 st century}

\section{Summary}

The article addresses an important and complex problem concerning the analysis of the implications of shaping a new international order for Germany's policy towards Russia.

It consists of three parts:

1. General tendencies of German research on changes in the international order,

2. The essence of the new German policy strategy vis-à-vis Russia,

3. Challenges for the implementation of Germany's policy towards Russia.

As the leading EU country with extensive global interests, Germany - being the fourth global economy - in the 21 st century benefited largely from the achievements of globalization and the international neoliberal order with the dominant role of the United States. In this context, cooperation with Russia as a strategic partner was of key importance to Germany. It was curtailed after Russia's transition to a policy of explicit aggression against Ukraine in 2014 (annexation of Crimea and support for separatists in Donbas), thus undermining the existing international order.

As a consequence of imposing sanctions on Russia - by the USA, NATO countries and the EU - the Kremlin's leadership team headed by W. Putin made a shift towards deepening cooperation with China, aiming at weakening US influence and building a competitive multilateral order. Tensions and difficulties in transatlantic relations against the background of "America first" policy of the new US president D. Trump from the beginning of 2017 prompted Germany to maintain relations with Russia and China in a bilateral and multilateral dimension.

Key words: Germany, Russia, new international order, political and economic cooperation 